REVIEW

\title{
Interleukin-1 in Disease
}

\author{
Charles A Dinarello \\ Department of Medicine, Tufts University School of Medicine, New England Medical Center Hospital, Boston, \\ $M A, U S A$
}

(Received for publication on February 7, 1994)

\begin{abstract}
As outlined in this review, the inflammatory cytokine interleukin-1 (IL-1) mediates a number of pathological processes associated with disease. To prove a role for $\mathbf{L}-1$, a variety of modalities have been used to block the production and/or activity of IL-1. These include agents which inhibit or reduce 1) IL-1 transcription and/or synthesis, 2) the processing of pro- $\mathrm{LL}-1 \beta$ into its mature forms, 3) the secretion of IL-1 $\beta, 4)$ the activity of IL-1 using neutralizing anti-IL-1 antibodies or 5) soluble (extracellular) IL-1 receptors, 6) the ability of $\mathrm{IL-1}$ to bind to its receptors using receptor blockade, 7) the availability of surface receptors using agents which down-regulate receptor expression or (8) agents which affect IL-1mediated signal transduction. Some of these modalities have already entered clinical trials. Clearly, the therapeutic advantage of reducing the activity of IL-1 resides in preventing its deleterious biological effects without interfering with host defense and homeostasis. For example, blocking IL-1-induced prostaglandins is one target in treating inflammatory diseases. Drugs inhibiting cyclooxygenase have well-known toxicities because they block the normal physiologic synthesis of prostaglandins in many tissues such as platelets and gastric lining cells. Blocking IL-1, in contrast, reduces only that portion of prostaglandin synthesis due to elevated IL-1, sparing the synthesis of prostaglandins necessary for physiologic homeostasis. A similar case can be made for endogenous nitric oxide. Thus, there is a unique pharmacological advantage to blocking IL-1 in disease. (Keio J Med 43 (3): 131-136, September 1994)
\end{abstract}

Key words: cytokines, soluble receptors, receptor antagonist, host defense

\section{Introduction}

Interleukin-1 (IL-1) consists of two structurally related polypeptides: IL- $1 \alpha$ and IL- $1 \beta$, each of which has a broad spectrum of biological activities. There is a third structurally related IL-1 molecule, IL-1 receptor antagonist (IL-1Ra) which inhibits the activities of IL-1. Among the properties of IL-1 ( $\alpha$ and $\beta$ ) are the ability to induce fever, sleep, anorexia, and hypotension. IL-1 stimulates the release of pituitary hormones, increases the synthesis of collagenases, resulting in cartilage destruction, and stimulates prostaglandin production, leading to a decrease in pain threshold. IL-1 also has been implicated in destruction of beta-cells of the islets of Langerhans, growth of acute and chronic myelogenous leukemia cells, inflammation associated with arthritis and colitis, and development of atherosclerotic plaques.

IL-1 actions can be direct on specific target tissues or indirect as an effector molecule. However, most activities of IL-1 are indirect. An example is the effect of IL-1 in the septic shock syndrome in which infection leads to the synthesis and release of large amounts of IL-1 that induce hypotension via the induction of platelet activating factor (PAF), prostaglandins (PG) and nitric oxide (NO). Another example of IL-1 as an effector molecule is autoimmune disease in which IL-1 contributes to tissue destruction because of its ability to stimulate collagenases and prostaglandins and induce bone resorption.

In most autoimmune diseases, $\mathrm{T}$ lymphocytes and not IL-1-producing phagocytic cells are the critical determinants of disease. The various treatments such as cyclosporine affect T-lymphocytes rather than mononuclear phagocytes. Any reduction in IL-1 production associated with immunosuppressive therapies is likely secondary to reduced T-lymphocyte stimulation of IL-1producing cells. Reducing the production of IL-1 in autoimmune diseases reduces the inflammatory effects

Presented at the 838th Mecting of The Keio Medical Society in Tokyo, October 21, 1993.

Reprint requests to: Dr Charles A Dinarello, Department of Medicine, Tufts University School of Medicine, New England Medical Center Hospital, 750 Washington Street, Boston, MA 02111, USA 
of IL-1 on target tissues such as the synovium, pancreatic islet cells or intestinal lining cells.

\section{Inhibition of Synthesis of IL-1}

IL-1 is rapidly synthesized by nearly every nucleated cell. Monocytic phagocytes when stimulated by microbial products produce the largest amounts of IL-1 per cell. A number of drugs, cytokines and other substances inhibit IL-1 production. Their action is not specific, however, since the production of other cytokines is usually inhibited as well. These agents may act at the level of transcriptional inhibition (corticosteroids) or translation inhibition (the dual inhibitors of cyclooxygenase and lipoxygenase). Targeting of specific nuclear transcription factors such as NFKB or AP-1 are being investigated.

Agents that reduce the transcription or translation of IL-1 are dependent on the type of stimulation of the cell being employed. For example, using endotoxin as a stimulus, interferon- $\gamma$ (IFN $\gamma$ ) enhances IL-1 translation whereas using IL-1 itself as a stimulant of IL-1 production, IFN $\gamma$ inhibits IL-1 synthesis. ${ }^{1,2}$ Another example is the effect of cyclooxygenase inhibitors. Using endotoxin as a stimulus, indomethacin enhances IL-1 translation whereas using IL-1 itself as a stimulant of IL-1 production, indomethacin inhibits IL-1 synthesis. ${ }^{3}$ Histamine, which increases cyclic AMP through the $\mathrm{H} 2$ receptor, enhances IL-1-induced IL-1. ${ }^{3}$ In fact, increases in cyclin AMP are likely the mechanism by which PG augment IL-1-induced IL-1 production. The effect of hsitamine is at the level of translation and not transcription. Thus, this mechanism may explain, in part, the efficacy of non-steroidal antiinflammatory agents.

\section{Inhibition of the proteolytic cleavage of the precursor of $I L-1 \beta$}

This is a mechanism for reducing IL-1 activity. IL-1 is first synthesized as a larger, precursor molecule. The precursors for IL- $1 \alpha$ and $\beta$ have molecular weights of $31,000 \mathrm{Da}$, but, unlike most proteins, both forms of IL-1 lack leader sequences that enable a precursor proteins to be cleaved to "mature" sizes. For both forms of IL-1, the mature sizes are $17-22,000 \mathrm{Da}$. Most IL- $1 \alpha$ remains in the cytosol where it may function more as an autocrine or juxtacrine messenger rather than as an extracellular mediator. There is also evidence that the precursor of IL- $1 \alpha$ is transported to the surface of the cell where it has been identified as "membrane" IL-1. Surface-bound IL- $1 \alpha$ precursor is biologically active.

On the other hand, a considerable amount of IL- $1 \beta$ is transported out of the cell where it can enter the circulation. Various mechanisms for transport include exocytosis from vesicles, active transport via mutiple drug resistance carrier proteins, "leakiness" or following cell death. Unlike the IL- $1 \alpha$ precursor, the IL- $1 \beta$ precursor requires cleavage for optimal biological activity. Several common enzymes (cathepsin $G$, elastase) will cut the IL-1 $\beta$ precursor into smaller and more active forms. However, one particular protease appears highly specific for cutting the IL- $1 \beta$ precursor from 31,000 to 17,500 , its most active form. ${ }^{4,5}$ This enzyme is known as the IL- $1 \beta$ converting enzyme (ICE). ICE is a member of the cysteine protease family. ICE does not cleave the IL- $1 \alpha$ precursor. Blocking ICE with ICE specific substrate inhibitors reduces the amout of mature IL- $1 \beta$ produced by activated monocytes. ${ }^{4}$

\section{Neutralization of IL-1 Activity}

Neutralizing antibodies to IL-1 $\beta$ reduce endotoxininduced fever in animals ${ }^{6}$ and decrease the proliferation of monocytic leukemia cells in vitro. ${ }^{7}$ Although antibodies to IL-1 have potential clinical value, most attention has focused on the development of soluble IL-1 receptors in order to neutralize IL-1.

\section{Soluble Receptors as a Strategy for Reducing L-1 Activity}

There are two IL-1 cell surface receptors (IL-1R). The type I IL-1R (IL-1RI) is found on most cells and appears to be important for transducing IL-1 activity. The type II IL-1 receptor (IL-1RII), is found primarily on neutrophils, monocytes, bone marrow cells and B-lymphocytes. The two IL-1R are members of the immunoglobulin superfamily and their binding sites for IL-1 are structurally similar. The IL-1RI receptor has a cytoplasmic segment and a higher affinity for IL-1 $\alpha$ than IL-1 $\beta$, whereas IL-1RII receptor has a short cytoplasmic segment and a higher affinity for IL- $1 \beta$ than IL- $1 \alpha$. Soluble receptors are the extracellular portions of the receptors that are cleaved from the cell surface. The function of the type II receptor appears to one of binding IL-1 without transmitting a signal. As such, it acts as a "decoy" for the type I receptor and reduces the activity of IL-1. ${ }^{8}$

Soluble IL-1RI and IL-1RII act like antibodies in that they specifically bind IL-1 and thereby prevent IL-1 binding to its receptors on cells. For example, administration of soluble IL-1RI receptors to mice with cardiac allografts increased graft survival and decreased lymph node swelling. ${ }^{9}$ This benefit of blocking IL-1 action is likely to be the result of decreased inflammation rather than immunosuppression. Early studies in humans suggest that soluble IL-1RI receptors can be administered safely and that they block inflammation. Since they are a component of the naturally occurring receptor, they are unlikely to elicit an immune response to a foreign 
antigen.

A naturally occurring soluble form of an IL-1 receptor has been identified in body fluids. ${ }^{10}$ This soluble IL-1 receptor is generated by proteolytic cleavage of the extracellular portion of the type II receptor. It specifically binds IL-1 and therefore prevents IL-1 binding to IL-1 receptors on cell surfaces. Low levels of this soluble receptor are found in the circulation of healthy subjects. It has been found in the synovial fluid of patients with rheumatoid arthritis and supernatants from stimulated peripheral blood mononuclear cells. Its concentrations in the circulation are increased in patients during acute reactivation of rheumatoid arthritis.

\section{Blocking IL-1 Receptors}

In animals, administration of antibodies to IL-1 type I receptors reduces inflammation and anorexia due to endotoxins and other inflammation-inducing agents. ${ }^{11}$ However, considerable information has accumulated pertaining to the blockade of IL-1 receptors using the naturally occurring IL-1Ra. ${ }^{12,13}$ This IL-1 antagonist belongs to the IL-1 gene family, it is produced by the same cells, and it has the same molecular size of mature IL-1 and is structurally related to it. Similar to the findings on IL-1, IL-1Ra is not present in peripheral blood monocytes or plasma from normal subjects but is found in the keratinocytes of the skin and in neuronal cells. IL-1Ra binds to cellular IL-1 receptors but this binding does not initiate any biological response. Lacking biological activity, it can be given in doses sufficient to occupy IL-1 receptors and therefore prevent bona fide IL-1 from binding to these same receptors.

Since both IL-1Ra and soluble IL-1R are specific inhibitors of IL-1, any modification of disease with the use of these agents would indicate a role for IL-1 in that

Table 1 Reducing IL-1 Activity

\begin{tabular}{|c|c|}
\hline Strategy & Agents $^{1)}$ \\
\hline Reduced Production & $\begin{array}{l}\text { Corticosteroids; } \omega-3 \text { fatty acids; } \\
\text { NSAIDs, CO/LO inhibitors; } \\
\text { TGF } \beta \text {; IL-4; IL-10; IL-13 }\end{array}$ \\
\hline Decreased Processing & $\begin{array}{l}\text { Inhibition of specific IL-1 } \\
\text { convertases (ICE) }\end{array}$ \\
\hline Neutralization & $\begin{array}{l}\text { Anti-IL-1 antibodies; } \\
\text { soluble IL-1 receptors }\end{array}$ \\
\hline Receptor Blockade & $\begin{array}{l}\text { Anti-receptor antibodies; } \\
\text { receptor antagonists }\end{array}$ \\
\hline $\begin{array}{l}\text { Downregulation of } \\
\text { Type I Receptor }\end{array}$ & TGF $\beta ;$ IL-1 \\
\hline $\begin{array}{l}\text { Upregulation of } \\
\text { Type II Receptor }\end{array}$ & IL-4 \\
\hline
\end{tabular}

1) Abbreviations: NSAIDs, non-steroidal anti-inflammatory drugs; $\mathrm{CO} / \mathrm{LO}$ inhibitors, cyclooxygenase/lipoxygenase inhibitors; TGF $\beta$, transforming growth factorb; ICE, IL-1 converting enzyme. particular disease. In fact, administration of IL-1Ra to animals, like administration of soluble IL-1R, reduce the severity of inflammation and some pathologic processes and improves survival. Examples of reduction in the severity of disease or its manifestations associated with IL-1 blockade are shown in Table 2.

IL-1 Ra appears to be a pure receptor antagonist. In a Phase I trial in normal subjects, plasma IL-1Ra concentrations of 25 to $30 \mathrm{mg} / \mathrm{ml}$ caused no symptoms or changes in vital signs and did not alter white blood cell counts or routine biochemical and endocrinologic tests. ${ }^{14}$ These results are consistent with the concept that IL-1 does not play an important role in normal physiologic homeostasis.

IL-1Ra has been given to human subjects injected with endotoxin. In this model, there is an associated neutrophilia and transient reduction in the proliferation of mononuclear cells to mitogens. In these volunteers, IL-1Ra was administered intravenously at 1,5 or $10 \mathrm{mg} / \mathrm{kg}$ over 3 hours. The endotoxin associated neutrophilia and transient reduction in the proliferation of mononuclear cells to mitogens was reversed by IL- $1 \mathrm{Ra} .{ }^{15}$ However, this was observed only at the $10 \mathrm{mg} / \mathrm{kg}$ dose.

\section{Blocking IL-1 in the Septic Shock Syndrome}

The mechanism of IL-1-induced shock appears to be its ability to increase mediator molecules such as PAF, PG and NO. These substances are potent vasodilators and induce shock in experimental animals. Blocking the action of IL-1 prevents the synthesis and release of these

Table 2 Reduction in Severity of Disease by Blocking IL-1 ${ }^{1)-3)}$

Death in Mice and Rabbits from Endotoxin

Death in Newborn Rats from Klebsiella pneumoniae

Shock in Rabbits and Baboons from E. coli or Staphylococcus epidermidis

Arthritis in Mice and Rats

Inflammatory Bowel Disease in Rabbits

Onset of Spontaneous Diabetes in the BB Rat

Hypoglycemia and CSF Production in Mice Following Endotoxin

Proliferation and CSF Production of Acute Myeloblastic and Chronic Myelogenous Leukemia Cells

Neutrophil Accumulation in Inflammatory Peritonitis

Sciatic Nerve Regeneration in Mice

Graft vs Host Disease in Mice

Endotoxin-induced Pulmonary Inflammation in Rats

Heart Allograft Rejection

Experimental Autoimmune Encephalomyelitis

Anorexia during the Inflammatory Response in Mice

1) Data are compiled, in part, from references. ${ }^{12,13,46}$ 2) Abbreviatios: $\mathrm{BB}$, bio-breeding; CSF, colony stimulating factor. 3) These studies used IL-1Ra to block IL-1, except for heart allograft rejection and experimental autoimmune encephalomyelitis where soluble IL-1 receptors were employed ${ }^{9,47}$ and in reducing anorexia associated with inflammation where antibodies to the IL-1 rcceptor were used. " 
mediators. In animals a single intravenous injection of IL-1 decreases mean arterial pressure, lowers systemic vascular resistance and induces leukopenia and thrombocytopenia. ${ }^{16,17}$ In humans intravenous administration of IL-1 also decreases blood pressure rapidly and doses of $300 \mathrm{ng} / \mathrm{kg}$ or greater may cause severe hypotension. ${ }^{18}$

There have been two clinical trials testing the efficiacy of IL-1Ra in patients with the sepsis syndrome. The first trial compared 4 groups 25 patients each, placebo and three doses of IL-1Ra infused over 72 hours. The two highest doses of 1 or $2 \mathrm{mg} / \mathrm{kg} / \mathrm{hr}$ ( 5 or 10 grams over 72 hours) revealed a significant reduction in 28 day mortality compared to placebo. The mortality rate in the placebo group was $44 \%$ and the reduction in the two groups of patients treated with IL-1Ra was 40 and $63 \%$, respectively $(\mathrm{p}=0.015){ }^{19}$

The study was expanded to 900 patients at 63 hospitals in 8 countries. This Phase III study was double-blinded, placebo controlled and tested the two doses of IL-1Ra ( 1 and $2 \mathrm{mg} / \mathrm{kg} / \mathrm{hr}$ for 72 hours). Analysis of 893 patients revealed a mortality rate of $34 \%$ in the placebo group, $31 \%$ in patients receiving $1 \mathrm{mg} / \mathrm{kg} / \mathrm{hr}$ and $29 \%$ patients treated with $2 \mathrm{mg} / \mathrm{kg} / \mathrm{hr}(\mathrm{p}=0.22)$. However, patients from the study were analyzed separately according to the severity of their disease upon entry as assessed by APACHE II (acute physiologic and chronic health evaluation) scores with a high risk of mortality $(>24 \%)$. In this subgroup, treatment with the high dose of IL-1Ra was statistically significant. In this high risk mortality group (595 patients), mortality in the placebo group was $45 \%, 37 \%$ in the group treated with $1 \mathrm{mg} / \mathrm{kg} / \mathrm{hr}$ and $35 \%$ in patients receiving $2 \mathrm{mg} / \mathrm{kg} / \mathrm{hr}(22 \%$ reduction in mortality, $\mathrm{p}=0.032$, Willcoxon). ${ }^{20}$

These data support laboratory and animal studies demonstrating that blockade of IL-1 is effective as the severity of disease increases whereas in less severe models, blocking IL-1 receptors has little or no effect. ${ }^{21.22}$ It also confirms previous studies that high circulating levels of IL-1Ra $(>20 \mathrm{mg} / \mathrm{ml})$ are required for IL-1 receptor blockade in vivo. ${ }^{23}$

\section{Blocking IL-1 in Inflammatory Diseases}

The best evidence that IL-1 contributes to the pathogenesis of inflammatory disease can be found in studies of animals with acute, immune complex-mediated colitis in which blocking IL-1 action with IL-1Ra reduces the severity of acute inflammation and decreases eicosanoid concentrations in affected bowel. ${ }^{24}$ A likely mechanism for these is that blocking the action of IL-1 reduces the amount of IL-8 that is produced in the inflamed bowel as it does in peripheral blood monocytes in vitro. ${ }^{25}$ The increased production of IL-1 and IL-8 in tissue specimens from patients with inflammatory bowel disease appears to come from mononuclear cells in the lamina propria of the bowel wall. Based on these results, clinical trials of IL-1Ra have been initiated in patients with ulcerative colitis.

\section{Blocking IL-1 in Acute and Chronic Myelogenous Leukemia}

IL-1 is a growth factor for acute and chronic myelogenous leukemia cells. Although IL- $1 \beta$ mRNA cannot be detected in peripheral blood cells or bone marrow aspirates from normal subjects, it can be detected in cells from patients with acute myelogenous leukemia. ${ }^{26}$ In addition, these leukemia cells produce an IL-1-like activity $^{27}$ as do chronic granulocytic leukemia cells of the juvenile type. ${ }^{28}$ These results do not necessarily implicate IL-1 as a cause of these leukemias. However, antibodies to IL- $1 \beta$ significantly reduce the spontaneous proliferation and colony formation of these cells in vitro, ${ }^{7}$ and IL-1Ra and an IL-1 inhibitor from human M20 leukemia cells similarly decrease the proliferation and colony formation of leukemic cells. ${ }^{26,29,30}$ Anti-IL-1-based therapy may be useful to inhibit or synchronize the growth of the leukemia cells so that they become more ulnerable to chemotherapeutic agents.

The IL-1 specific precursor-converting enzyme is found in large amounts in myelogenous leukemia cells. ${ }^{5}$ One approach to reduce the action of IL-1 in myelogenous leukemia therefore would be to prevent the proteolytic cleavage of the IL-1 precursor to an active form.

\section{Does blocking IL-1 impair host defense mechanisms?}

Patients with sepsis have plasma levels of IL- $1 \beta$ in the range of $250-500 \mathrm{pg} / \mathrm{ml}$ and rarely over $1 \mathrm{ng} / \mathrm{mg} .{ }^{31}$ In some studies in this patient population, there is a direct correlation between the level of plasma IL-1 $\beta$ and mortality. ${ }^{32}$ However, plasma concentrations of $30 \mathrm{mg} / \mathrm{ml}$ of IL-1Ra (representing a 10,000 fold molar excess) sustained over three days in humans with the septic shock syndrome is associated with improved survival. In healthy human subjects, these same concentrations sustained over 3 hours appear to be without detectable detrimental effects including tests of immune responses. ${ }^{14,15}$ This is consistent with in virto experiments in which blocking IL-1 did not diminish the response of human $\mathrm{T}$-cells to antigens. ${ }^{33}$ Although there are no long term human data available at the present time, blocking IL-1 is likely to be safe, at least in the short term. Since the treatment of some IL-1-mediated diseases may require prolonged use, the question arises whether sustained blockade of IL-1 will weaken host defense mechanisms.

On the other hand, there is no dearth of experimental data illustrating a role for IL-1 in boosting natural host 
defense mechanisms. For example, IL-1 protects the early stem cells against radiation damage,,$^{34}$ can act as an adjuvant $^{35}$ and improves survival of granulocytopenic mice with lethal Pseudomonas infection. ${ }^{36}$ How can IL-1 improve survival while blocking IL-1 may accomplish the some endpoint? Thus, small amounts of IL-1 produced in disease are necessary for maintaining natural host defenses, whereas high amounts of IL-1 are lethal. In some animal models of infections, blocking IL-1 increases mortality ${ }^{37,38}$ Clinical evidence supports this concept. In some patients with sepsis, these is a statistically significant correlation with survival and production of IL-1 whereas failure to produce IL-1 is associated with death. ${ }^{31,39}$ However, blocking high levels of IL-1 as occurs in disease will reduce inflammation and the severe consequences of this cytokine. It is presently unclear whether total blockade of IL-1 is advisable or even acheivable in the clinical setting.

\section{Differential Production of IL-1 and IL-1Ra}

The production of IL-1 and IL-1Ra is differentially regulated even in the same cell, although the same cell synthesizes both cytokines. ${ }^{40}$ For example, in a cell stimulated with endotoxin, the expression of the IL- $1 \beta$ gene takes place before IL-1Ra. ${ }^{41}$ In addition, triggering of the receptor for immunoglobulin on the monocyte stimulates IL-1Ra but not IL-1 production. In human subjects injected with a small amount of endotoxin, levels of IL-1Ra are 100 -fold greater than IL-1 $\beta .^{42}$ In contrast, unlike endotoxin, Borrelia burgdorferi induces more IL-1 $\beta$ than IL- $1 \mathrm{Ra}^{43}$ and the expression of IL-1Ra in acute myelogenous leukemia cells is suppressed whereas IL-1 $\beta$ is produced spontaneously. ${ }^{26}$

Other cytokines may also contribute to the balance of IL-1 and IL-1Ra production during disease. For example, IL- 4 , transforming growth factor- $\beta$ and IL- 10 have the interesting property of increasing the synthesis of IL-1Ra but at the same time decreasing the synthesis of IL-1. ${ }^{H}$ The efficacy of these cytokines in various inflammatory diseases may include their ability to regulate the balance of the agonist to the antagonist. A special example of this balance exists in the skin. Skin keratinocytes contain large amounts of IL-1a which remain within the cell. A form of IL-1Ra is found in 10-100-fold higher concentrations in the keratinocytes. This intracellular IL-1Ra may be serving a role as an anti-inflammatory agent buffering the inflammatory properties of IL-1 released from the skin following injury. ${ }^{45}$

Acknowledgements: These studies are supported by NIH Grant AI 15614 from the National Institutes of Health. The authors thank Drs Jeffrey A Gelfand, Joseph G Cannon, and Sheldon M Wolff. Dr Dinarello does not serve as an advisor nor receive financial support from Synergen, Inc. or Immuncx Corp.

\section{References}

1. Ghezzi P, Dinarello CA: IL-1 induces IL-1. III. Specific inhibition of IL-1 production by IFN- $\gamma$. J Immunol 1988, 140: 4238-4244

2. Schindler R, Ghezzi P, Dinarello CA: IL-1 induces IL-1. IV. IFN- $\gamma$ suppresses IL-1 but not lipopolysaccharide-induced transcription of IL-1. J Immunol 1990, 144: 2216-2222

3. Vannier E, Dinarello CA: Histamine enhances interleukin (IL)-1-induced IL-1 gene expression and protein synthesis via $\mathrm{H}_{2}$ receptors in peripheral blood mononuclear cells: comparison with IL-1 receptor antagonist. J Clin Invest 1993, 92: 281-287

4. Thornberry NA, Bull HG, Calaycay JR, Chapman KT, Howard AD, Kostura MJ, Miller DK, Molineaux SM, Weidner JR, Aunins $\mathbf{J}$, et al: A novel heterodimeric cysteine protease is required for interleukin-1 $\beta$ processing in monocytes. Nature 1992 , 356: $768-774$

5. Cerretti DP, Kozlosky CJ, Mosley B, Nelson N, Van Ness K, Greenstreet TA, March CJ, Kronheim SR, Druck T, Cannizzaro LA, Huebner K, Black RA: Molecular cloning of the IL- $1 \beta$ processing enzyme. Science 1992, 256: 97-100

6. LeMay LG, Otterness IG, Vander AJ, Kluger MJ: In vivo evidence that the rise in plasma IL- 6 following injection of a fever-inducing dose of LPS is mediated by IL-1 $\beta$. Cytokine 1990, 2: 199-204

7. Cozzolino F. Rubartelli A, Aldinucci D, Sitia R, Torcia M, Shaw A, Di Guglielmo R: Interleukin 1 as an autocrine growth factor for acute mycloid leukemia cells. Proc Natl Acad Sci USA 1989 , 86: $2369-2373$

8. Colotta F, Re F, Muzio M, Bertini R, Polentarutti N, Sironi M. Giri JG, Dower SK, Sims JE, Mantovani A: Interleukin-1 type II receptor: a decoy target for IL-1 that is regulated by IL-4. Science 1993, 261: 472-475

9. Fanslow WC, Sims JE, Sassenfeld H, Morrissey PJ, Gillis S, Dower SK, Widmer MB: Regulation of alloreactivity in vivo by a soluble form of the intcrlcukin-1 receptor. Science 1990, 248 : $739-742$

10. Symons JA, Eastgate JA. Duff GW: Purification and characterization of a novel soluble receptor for interleukin-1. J Exp Med 1991, 17.4: 1251-1254

11. Gershenwald JE, Fong YM, Fahey TJ, Calvano SE, Chizzonite R, Kilian PL, Lowry SF, Moldawer LL: Interlcukin 1 receptor blockade attenuates the host inflammatory response. Proc Natl Acad Sci USA 1990, 87: 4966-4970

12. Arend WP: Interleukin-1 receptor antagonist. A new member of the interleukin 1 family. J Clin Invest 1991, 88: 1445-1451

13. Dinarello CA, Thompson RC: Blocking IL-1: interleukin 1 receptor antagonist in vivo and in vitro. Immunol Today 1991, 12: $404-410$

14. Granowitz EV, Porat R, Micr JW, Pribble JP, Stiles DM, Blocdow DC, Catalano MA, Wolff SM, Dinarcllo CA: Pharmacokinetics, saftey, and immunomodulatory effects of human recombinant interleukin-1 receptor antagonist in healthy humans. Cytokine 1992, 4: 353-360

15. Granowitz EV, Porat R, Micr JW, Orencolc SF, Callahan MV, Cannon JG, Lynch EA, Yc K, Poutsiaka DD, Vannier E, Shapiro L. Pribble JP, Stilcs DM, Catalano MA. Wolff SM, Dinarello CA: Hematologic and Immunomodulatory effects of an interleukin-1 receptor antagonist coinfusion during low-dose endotoxemia in healthy humans. Blood 1993, 82: 2985-2990

16. Okusawa S, Gelfand JA, Ikcjima T, Connolly RJ, Dinarello CA: Interleukin 1 induces a shock-like state in rabbits. Synergism with tumor necrosis factor and the effect of cyclooxygenase inhibition. J Clin Invest 1988, 81: 1162-1172

17. Fischer E, Marano MA, Barber AE, Hudson A, Lec K, Rock CS, Hawes AS, Thompson RC, Hayes TJ, Anderson TD, Benjamin WR, Lowry SF, Moldawer LL: Comparison between effects of 
interleukin- $1 \alpha$ administration and sublethal endotoxemia in primates. Am J Physiol 1991, 261 (Pt2): R442-R452

18. Smith JW2, Urba WJ, Curti BD, Elwood LJ, Steis RG, Janik JE, Sharfman WH, Miller LL, Fenton RG, Conlon KC, Rossio J, Kopp W, Shimuzut M. Oppenheim JJ, Longo D: The toxic and hematologic effects of interleukin- $1 \alpha$ administered in a phase I trial to patients with advanced malignancies. J Clin Oncol 1992, 10: $1141-1152$

19. Fisher CJJ, Slotman GJ, Opal SM, Pribble J, Bone RC, Emmanuel G, Ng D, Bloedow DC, Catalano MA: Initial evaluation of human recombinant interleukin-1 receptor antagonist in the treatment of sepsis syndromc: a randomized, open-label, placebo-controlled multicenter trial. Crit Care Mcd 1994, 22: 12-21

20. Fisher CJJ, Dhainaut JF, Pribble J, Knaus W, Catalano MA, Group I-1PIS: A study evaluating the efficacy of human recombinant interleukin-1 receptor antagonist in the treatment of patients with sepsis syndrome: preliminary results from a Phase III multicenter trial. 13th Intl Sym Intensive Carc Emerg Med 1993. Brussels: (abs)

21. Fischer E. Marano MA, van Zee KJ, Rock CS, Hawes AS, Thompson WA, DeForge L, Kenney JS, Remick DG, Bloedow DC, Thompson RC, Lowry SF, Moldawer LL: Interleukin-1 receptor blockade improves survival and hemodynamic performance in Escherichia coli septic shock, but fails to alter host responses to sublcthal endotoxemia. J Clin Invest 1992, 89: $1551-1557$

22. Aiura K, Gelfand JA, Burke JF, Thompson RC, Dinarello CA: Interlcukin-1 (IL-1) reccptor antagonist prevents Staphylococcus epidermidis-induced hypotcnsion and reduces circulating levels of tumor necrosis factor and IL-1 $\beta$ in rabbits. Infect Immun 1993. $61: 3342-3350$

23. Ohlsson K, Bjork P, Bergenfeldt M, Hageman R, Thompson $\mathrm{RC}$ : Interleukin-1 receptor antagonist reduces mortality from cndotoxin shock. Nature 1990, 348: 550-552

24. Cominelli F, Nast CC, Clark BD, Schindler R, Llerena R, Eysselein VE, Thompson RC, Dinarcllo CA: Interleukin l (IL-1) gene expression, synthesis, and effect of specific IL-1 receptor blockade in rabbit immunc complex colitis. J Clin Invest 1990, 86: 972-980

25. Porat R, Poutsiaka DD, Miller LC, Granowitz EV, Dinarello CA: Interleukin-1 (IL-1) receptor blockade reduces endotoxin and Borrelia burgdorferi-stimulated IL-8 synthesis in human mononuclear cells. FASEB J 1992, 6: 2482-2486

26. Rambaldi A, Torcia M, Bettoni S, Vannier E, Barbui T, Shaw AR, Dinarello CA, Cozzolino F: Modulation of cell proliferation and cytokine production in acutc mycloblastic leukemia by interleukin-1 receptor antagonist and lack of its expression by lcukemic cells. Blood 1991, 78: 3248-3253

27. Griffin JD, Rambaldi A, Vellenga E, Young DC, Ostapovicz D, Cannistra SA: Secretion of interleukin-1 by acutc myeloblastic leukemia cells in vitro induces endothelial cells to secrete colony stimulating factors. Blood 1987, 70: 1218-1221

28. Bagby GCJ, Dinarcllo CA, Nccrhout RC, Ridgway D, McCall E: Interleukin 1-dependent paracrine granulopoiesis in chronic granulocytic leukemia of the juvenile type. J Clin Invest 1988, 82: $1430-1436$

29. Estrov Z, Kurzrock R, Wetzler M, Kantarjian H, Blake M, Harris D, Gutterman JU, Talpaz M: Suppression of chronic myelogenous leukemia colony growth by IL-1 receptor antagonist and soluble IL-1 receptors: a novel application for inhibitors of IL-1 activity. Blood 1991, 78: 1476-1484

30. Peled T, Rigel M, Pcritt D, Fibach E, Treves AJ, Barak V: Effect of M20 interleukin-1 inhibitor on normal and leukcmia human myeloid progenitors. Blood 1992, 79: 1172-1177

31. Cannon JG, Friedberg JS, Gclfand JA, Tompkins RG, Burke JF,
Dinarello CA: Circulating interleukin-1 $\beta$ and tumor necrosis factor- $\alpha$ concentrations after burn injury in humans. Crit Care Med 1992, 20: 1414-1419

32. Casey LC, Balk RA, Bone RC: Plasma cytokines and endotoxin levels correlate with survival in patients with the sepsis syndrome. Ann Intern Med 1993, 119: 771-778

33. Nicod LP, El Habre F, Dayer JM: Natural and recombinant interleukin 1 receptor antagonist does not inhibit human T-cell proliferation induced by mitogens, soluble antigens or allogeneic determinants. Cytokine 1992, 4: 29-35

34. Neta R, Oppenheim JJ, Douches SD: Interdependence of the radioprotective effects of human recombinant interleukin- $1 \alpha$, tumor necrosis factor $\alpha$, granulocyte colony-stimulating factor, and murine rccombinant granulocyte-macrophage colonystimulating factor. J Immunol 1988, 140: 108-111

35. Boraschi D, Villa L, Volpini G, Boss'u P, Censini S, Ghlara P, Scapigliat G, Nencioni L, Bartalini M, Matteucci G: Differential activity of interleukin- $1 \alpha$ and interleukin- $1 \beta$ in the stimulation of the immune response in vivo. Eur J Immunol 1990, 20: 317-321

36. van der Meer JWM, Barza M, Wolff SM, Dinarello CA: A low dose of recombinant interleukin 1 protects granulocytopenic mice from lethal gram-negative infection. Proc Natl Acad Sci USA 1988, 85: $1620-1623$

37. Havell EA, Moldawer LL, Helfgott D, Kilian PL, Sehgal PB: Type I IL-1 receptor blockade exacerbates murine listeriosis. J Immunol 1992, 148: 1486-1492

38. Mancilla J, García P, Dinarello CA: The interleukin-1 receptor antagonist can either reduce or enhance the lethality of Klebsiella pneumonia sepsis in newborn rats. Infect Immun 1993, 61: $926-932$

39. Munoz C, Carlet J, Fitting C, Misset B, Bieriot JP, Cavaillon JM: Dysregulation of in vitro cytokine production by monocytes during sepsis. J Clin Invest 1991, 88: 1747-1754

40. Andersson J, Björk L, Dinarello CA, Towbin H, Andersson U: Lipopolysaccharide induces human interleukin-1 receptor antagonist and interleukin-1 production in the same cell. Eur J Immunol 1992, 22: 2617-2623

41. Arend WP, Smith MFJ, Janson RW, Joslin FG: IL-1 receptor antagonist and $\mathrm{IL}-1 \beta$ production in human monocytes are regulated differently. J Immunol 1991, 147: 1530-1536

42. Granowitz EV, Santos AA, Poutsiaka DD, Cannon JG, Wilmore DW, Wolff SM, Dinarello CA: Production of interleukin-1receptor antagonist during experimental endotoxaemia. Lancet 1991, 338: 1423-1424

43. Miller LC, Isa S, Vannier E, Georgilis K, Steere AC, Dinarello CA: Live Borrelia burgdorferi preferentially activate interleukin$1 \beta$ genc expression and protein synthesis over the interleukin-1 rcceptor antagonist. J Clin Invest 1992, 90: 906-912

44. Vannicr E, Miller LC, Dinarello CA: Coordinated antiinflammatory effects of interleukin 4: interleukin 4 suppresses interleukin 1 production but up-rcgulates gene expression and synthesis of interleukin 1 receptor antagonist. Proc Natl Acad Sci 1992, 89: $4076-4080$

45. Haskill S, Martin G, Van Le L, Morris J, Peace A, Bigler CF, Jaffe GJ, Hammerberg C, Sporn SA, Fong S, Arend WP, Ralph $P$ : cDNA cloning of an intracellular form of the human interleukin 1 rcceptor antagonist associated with epithelium. Proc Natl Acad Sci USA 1991, 88: 3681-3685

46. Dinarcllo CA: Interleukin-1 and interleukin-1 antagonism. Blood 1991, 77: 1627-1652

47. Jacobs CA, Baker PE, Roux ER, Picha KS, Toivola B, Waugh S, Kennedy MK: Expcrimental autoimmune encephalomyelitis is exacerbated by IL-1 $\alpha$ and suppressed by soluble IL- 1 receptor. J Immunol 1991, 146: 2983-2989 